\title{
GOVERNMENT, OPENNESS AND FINANCE: PAST AND PRESENT
}

\author{
by \\ PANICOS O. DEMETRIADES \\ University of Leicester \\ and \\ PETER L. ROUSSEAU ${ }^{\dagger}$ \\ Vanderbilt University and National Bureau of Economic Research
}

We explore the role of government in the nexus of finance and trade starting from the earliest days of organised finance in England and then broadening the analysis to 84 countries from 1960 to 2004. For 18th century England, we find that the government expenditures and international trade did have a positive effect on financial development when measured as the value of private loans issued at the Bank of England. For the wider panel of countries and more recent data, we find that government expenditures and trade have positive effects on financial development for countries that are in the mid-ranges of economic development as measured by their per capita incomes, but have little effect for poor countries and strongly negative effects for the wealthiest ones.

Revised April 2011

\footnotetext{
${ }^{+}$We are grateful to the ESRC and SSRC for financial support in the form of a Visiting Fellowship for Peter L. Rousseau at the University of Leicester and Birkbeck College of the University of London in the Summer of 2009 and 2010.
} 


\section{INTRODUCTION}

Economic historians have long recognised that governments are central to the development of organised finance and the smooth operation of trading arrangements (North and Weingast, 1989). Indeed, the experiences of the 17th-century Dutch Republic, 18th-century England, and the 19th-century United States offer powerful narratives to support this view. ${ }^{1}$ Yet the role of governments in fostering growth through improved institutions has received less attention in modern macroeconomic and development studies that use more recent data. This is not to say, however, that economists have ignored the role of institutions in promoting growth over the post-World War II period. On the contrary, a battery of empirical studies published over the past two decades point to a first-order importance of financial development in promoting long-run economic growth, and have elevated the proposition to something of a stylised fact (Levine, $1997,2005){ }^{2}$ At the same time, a largely independent literature indicates a positive role for trade openness and export orientation in long-run growth, especially when tested over the latter half of the twentieth century with data for a broad set of countries (Dollar, 1992; Ben-David, 1993; Sachs and Warner, 1995; Edwards, 1998).

Much of the research on financial development in recent years, however, has shifted from

\footnotetext{
${ }^{1}$ See, for example, de Vries (1976) and de Vries and van der Woude (1997) on the Dutch Republic, Dickson (1967) and Brewer (1989) on England, Neal (1990) on integration of the London and Amsterdam markets, and Sylla (1999) on the United States. More recent comparative studies of these countries and others include Rousseau (2003), Rousseau and Sylla (2003) and Andrianova et al. (2008).

${ }^{2}$ This is not to say that there is universal agreement on the direction of causation (Demetriades and Hussein, 1996), the extent to which the effect is generalisable to a wide range of countries (Rioja and Valev, 2004), or whether the relationship has weakened over the past twenty years (Rousseau and Wachtel, 2011).
} 
measuring the growth effects of finance to learning more about what determines financial development itself. It is in this area that the link between finance and trade has received some attention (Svaleryd and Vlachos, 2002; Baltagi et al., 2009). Here we extend this line of inquiry by bringing governments into the nexus of finance and trade, starting with 18th century England and then broadening the analysis to 84 countries using data from 1960 to the present.

Our starting point is historical. In the early stages of economic and financial development, countries may find themselves caught in an under-development trap. The absence of financial markets, both domestic and international, combined with an under-developed tax base and inefficiencies in tax administration can lead to governments that are cash constrained. Without sufficient funds, governments are unable to undertake much needed public investments in hard and soft infrastructure, education and health. Inadequate transportation networks, rudimentary law and order systems, and ill and/or illiterate populations can create insurmountable obstacles for industrial take-off. ${ }^{3}$ In such circumstances, opportunities for profitable private investment are rare. Where present, they can be very risky. And without insurance markets, the risks are likely to be unacceptably high for entrepreneurs. As a result the demand for private finance may be negligible or non-existent. In such a bad equilibrium, financial and economic underdevelopment are two sides of the same coin.

Trade offers a way to break out of the under-development trap. However, history has shown that this requires a high degree of co-ordination between private and public sectors. Trade can be highly profitable if it is secure yet the profits can easily be competed away. As

\footnotetext{
${ }^{3}$ The critical role of infrastructure in promoting industrial take-off is documented by Easterly and Rebelo (1993). There is also a large literature on the positive effects of infrastructure on private investment, trade and economic growth (Bougheas, Demetriades and Morgenroth, 1999; Bougheas, Demetriades and Mamuneas, 2000).
} 
Andrianova et al. (2011) and others have argued, the emergence of London as a financial market in the latter part of the 17 th century owes a lot to the monopoly rights granted by government to all the leading joint stock companies. These rights guaranteed high returns to investors and helped to mobilise saving (the share issues of the East India Company, for example, were typically over-subscribed). The rise of the great trading companies in turn promoted development of a modern commercial sector. The monopoly rights were granted at a price: the joint stock companies made very significant long-term loans to the government. These loans were so large that they transformed the state of the public finances. As Rousseau (2003) shows, the rise in real incomes that followed the expansion of trade set in motion a virtuous financetrade-growth cycle which helped to propel England from a weak state in the early part of the 17 th century to Europe's foremost military power by the beginning of the 18 th century and the world's clear financial leader by its end. ${ }^{4}$

Given the central role of governments in promoting financial and commercial development in history, might we expect to see similar patterns today in developing countries? We think that the answer is yes, although the picture can be more complex because developing countries today have greater (yet still varying degrees of) access to world capital markets and foreign aid. For the poorest developing countries, foreign aid is an important mechanism for financing trade-promoting infrastructure and public investment in health and education. As a result, the link between government spending and domestic financial development may be weaker than it is likely to have been, for example, in 18th century England, where governments

\footnotetext{
${ }^{4}$ Similar events were realised a century earlier in Amsterdam. The Dutch East India Company, which had very close links to the Dutch state, was formed in 1602 by royal charter following demands by its predecessors who saw their profits eroded by competition. The emergence of the stock market in Amsterdam is firmly linked to the establishment of the Company (Neal, 1990).
} 
tapped much if not all of their finance domestically. For the same reason, we would expect a stronger link between government and domestic financial development in middle income countries.

First, however, it is appropriate to consider $18^{\text {th }}$ century England, often touted as the classic case of the centrality of the State in modern economic emergence.

\section{18TH CENTURY ENGLAND}

\subsection{Background}

Modern studies of the role of the state in 18th century British growth tend to focus on the extent to which wartime expenditures led to a crowding out of private sector investments, thereby slowing overall economic growth (Williamson, 1984; Crafts, 1987; Mokyr, 1987). But if disbursements by the exchequer are a weak proxy for the output of the government, as Jackson (1990) has argued, the multiplier of actual government expenditure may have been larger, in which case crowding out would have been less severe.

Fig. 1 shows total government expenditure from 1720 along with total trade (i.e., the sum of imports, exports, and re-exports), all in per capita 1740 sterling. ${ }^{5}$ The four large spikes in the expenditure series corresponding with the War of Austrian Succession (1740-48), the Seven Years War (1754-63), the American Revolutionary War (1775-83), and the Wars of the First and

\footnotetext{
${ }^{5}$ Government expenditures are the sum of civil and military spending from Mitchell (1988, Table 11.2, pp. 578-80). The trade data are from Mitchell (1988, Table 10.1.A, pp. 448-9 for England and Wales for 1720-91, and Table 10.1.B, p. 450 for Great Britain 1792-99). To form a single series for trade openness we join the broader aggregate for Great Britain to the narrower series for England and Wales. We deflate all of our data to reflect 1740 prices using the Schumpeter-Gilboy price index for consumer goods (Mitchell, 1988, Table 14.1.B, pp. 719-20) and convert them into per capita terms using population data for England (excluding Monmouthshire) from Mitchell (1988, Table 1.1.A, pp. 7-8).
} 
Second Coalitions (1793-1802). ${ }^{6}$ It would seem that large lumpy expenditures such as these could not have been conducive to an industrial take-off. Yet total trade, a rough proxy for activity in the commercial (i.e., modern) sector of the economy, with the exception of the American Revolutionary period, does not fluctuate sharply and negatively with government expenditure. Rather, the two series have a positive correlation coefficient of 0.49 , with international trade rising by 88 percent between 1720 and 1799 despite the American War.

\section{[INSERT FIG. 1 HERE]}

At the same time that trade was rising dramatically, England was in the midst of a commercial and industrial revolution. And when the time series for trade in Fig. 1 is considered in light of earlier data for the East India Company that indicate a more than six-fold increase in Asian exports between 1660 and 1710, the rapid commercialisation of the British economy comes into clear focus. It is interesting to note that Hoffman's index of industrial production (Mitchell, 1988, Table 8.21.A, pp. 431-432, including building), progresses less rapidly than the trade series at first, but accelerates after 1780, and thus seems to share the rhythm of the later part of the trade boom.

The positive relation between government expenditure and trade requires explanation. Was the crowding out suggested by earlier studies a short-run phenomenon while state interventions promoted growth in a long-term sense through a less direct "big push" mechanism? We argue here that such a push started with public sector investments that raised income, production, trade, and bank deposits, with the latter providing significant feedback effects to the

\footnotetext{
${ }^{6}$ Our sample period was preceded by the War of Spanish Succession (1700-14) and by the Nine Years War (1688-97), the latter commencing with the Glorious Revolution of 1688.
} 
commercial sector as the Bank of England shifted its asset portfolio towards private loans. This allowed government expenditure, finance, and commerce, as measured by the extent of trading activity, to interact in a complementary manner.

The main public expenditure early on, of course, involved gearing up for war, and a positive interaction between the government and banking began as Parliament strove to raise finance for the Nine-Years War against France in 1688. A key problem for the government at the time was the illiquidity of its own bonds, so it formed the Bank of England in 1694 to buy and hold this debt while the underlying capitalisation of the Bank itself could trade with greater liquidity on the newly-formed London stock market. ${ }^{7}$ Over the next fifty years, the Bank would become, to quote R. D. Richards (1934, p. 272), “a credit institution, an organ of State Finance, a discount and issuing house, a bullion warehouse, and a safe repository."

Shortly after its founding, the Bank re-coined the nation's metallic currency and engaged in various note-issuing experiments, both of which promoted monetisation and brought some degree of order to the fledgling financial system. The dashed line in Fig. 2 shows how the real per capita liabilities of the Bank (i.e., the sum of its circulation and deposits) increased rapidly through the early 1730s before declining slightly and then levelling off for the remainder of the century. ${ }^{8}$ The ability of the Bank to bring about intensive growth in ordinary deposits early on

\footnotetext{
${ }^{7}$ The stock exchange facilitated transactions in public debt securities and shares of the large trading companies, including the British East and West India Companies, the South Sea Company, and the Royal African Company.

${ }^{8}$ We obtain the Bank's deposit and circulation liabilities from Mitchell (1988, Table 12.2.A, pp. 655-58). It is probably fair to say that coin and Bank of England notes accounted for most of the circulating medium it in London and elsewhere before 1750 given that London's private bankers had stopped issuing notes, which were always a small part of their business, long before 1775 due to competition from the Bank of England (Cameron, 1967, p. 22). But an increase in the
} 
proved essential to supporting the government expenditures that would become necessary in the 1740s and 1750s. Even the extensive growth in deposits after 1750, though not impressive, was considerable given the 50 percent increase in England's population between 1750 and $1799 .{ }^{9}$

[INSERT FIG. 2 HERE]

But while the Bank's relationship with the State has received the most attention among scholars, the Bank also offered considerable support to London's merchant and trading communities through its clearing and discounting facilities (Clapham, 1941). The solid line in Fig. 2 shows the extent of the Bank of England's private loan business, which grew rapidly from the $1750 \mathrm{~s}$, even approaching the size of its deposit and circulation liabilities during the $1760 \mathrm{~s}$ and again by $1800 .{ }^{10}$ Much of this activity was accomplished through the Bank's “drawing accounts," though not all those with accounts were entitled to advances. ${ }^{11}$ Evidence from the Bank archives described in Clapham $(1941,1945)$ show that loans and discounts were spread

number of country banks after 1775 and a lack of reliable information on net specie imports make us unable to build a continuous series for an M2-like aggregate.

${ }^{9}$ Since the Bank's deposit and circulation liabilities were presumably zero before its founding in 1694, their growth prior to the start of our data in 1720 must have been very rapid. This apparent rise in liabilities, for which we see only the tail end in Fig. 2, also coincided with another spike in government expenditures during the War of Spanish Succession (1700-14).

${ }^{10} \mathrm{We}$ build this series as the income from discounting bills and notes and making private loans (Clapham, 1945, Vol. 1, Appendix E, pp. 301-2 and Vol. II, Appendix C, p. 433) divided by the Bank rate over the previous year (Clapham, 1945, Vol. I, Appendix D, p. 299, and Vol. II, Appendix B, pp. 429). This assumes that the Bank of England's loans were primarily short term, which is consistent with Clapham's reading of the loan records.

${ }^{11}$ The Bank also made over ninety loans to the East India Company between 1709 and 1744, but these loans, though exceeding other bill and note discounts in the Bank's early days, did not become an important component of the asset portfolio until the 1750s. 
across a wide range of commercial activities, and that discounts below the statutory limit of $£ 50$ were not unusual. And as liabilities struggled to keep up with population by the late 1730s, the Bank's capital and deposits were increasingly deployed toward the provision of private loans, some of which were used to facilitate trade. With the large trading companies making loans to the government through the Bank of England, and these (often military) expenditures making their way back into the deposit liabilities of the Bank, we believe that the rise and accompanying fluctuations in the amount and availability of private loans could have strongly influenced commerce just as the industrial economy hit its stride after 1760 .

The Bank's private loans may also be representative of commercial lending in England more generally because, before 1750, the Bank of England co-existed in the provision of banking services only with a group of private bankers in London who dealt primarily in deposits and bills of exchange. This gave rise to an active money market to finance trade and working capital for the emerging manufacturing sector, and the Bank had a central role in its operation. Moreover, England was slow to develop private banks compared to the pace at which they would grow in the United States only 50 years later. ${ }^{12}$

\subsection{Empirical Analysis}

Is the available evidence for 18th century England consistent with virtuous cycles of government expenditure, trade and financial development? Though our historical focus limits the richness of the data items that can be brought to bear on our hypothesis, the data depicted in Fig. 1 and Fig. 2 are sufficient for conducting at least a basic time series investigation. We limit

\footnotetext{
${ }^{12}$ Relatively little is known about the extent of country banking in 18th century England. These banks were generally small, but grew in number. Cameron (1967, pp. 23-24) estimates that "about a dozen" existed in 1750, about 100 in the early 1780s, and about 300 by 1800 .
} 
the time coverage to 1728 to 1799 because this represents the period for which reliable data on private loans of the Bank of England are continuously available on an annual basis. We have argued above that this variable might capture the intensity of financial intermediation well.

Table 1 provides time-series evidence of the relationship between government expenditure, trade openness and financial development, with all three variables measured on a real, per capita basis. The upper panel reports results from a vector autoregressive (VAR) model estimated in log levels. ${ }^{13}$ Both trade and government expenditure Granger-cause private loans at the five percent level or less with the regression coefficients for each variable summing to a positive value. This suggests that both of these variables drive financial development, which is consistent with our view of the mechanism at work.

[INSERT TABLE 1 HERE]

The Johansen (1991) tests for co-integration reported in center panel of Table 1 show a single long-term relationship among the three variables, with both the trace and maximum eigenvalue statistics rejecting the null of no co-integration and failing to reject the null of a single co-integrating vector.

The lower panel of Table 1 reports estimates from the corresponding vector error

\footnotetext{
${ }^{13}$ Before estimating the VAR, we tested each series for non-stationarity using Augmented Dickey-Fuller (ADF) tests. We were unable to reject the null hypothesis of a unit root for any of these series using three to five additional lag differences in the test regressions. All three series rejected the null in first differences. Since our Johansen (1991) tests indicate that the series share a single co-integrating relationship, a VAR model in levels is appropriate (Sims et al., 1990). We determine the lag order of the VAR using a series of nested likelihood ratio tests. The Grangercausality inferences are qualitatively the same when we apply the modified Wald tests developed by Toda and Yamamoto (1995).
} 
correction model (Banerjee et al., 1993). ${ }^{14}$ These VECM results confirm the exogeneity of trade suggested by the levels VAR. They also indicate that financial development is not weakly exogenous to the system. The negative and significant sum of the regression coefficients on first differences of both government expenditure and trade in the private loans equation suggest that both crowded out Bank of England private loans in the short-run. The negative sign on the error correction term (ECT) in the private loans equation, however, when viewed with the negative loadings on trade and government expenditure in the normalised co-integrating vector, is also consistent with financial development responding positively in the long run to perturbations to the ECT caused by increases in trade openness and government expenditure. This is similar to the overall effects reported for the levels VAR in the upper panel. The final equation of the VECM indicates that government expenditure is also not weakly exogenous, suggesting that financial development may have had positive long-run effects on the resources available to the government.

The cumulative impulse responses depicted in Fig. 3 and Fig. 4 confirm the positive long run effects of government expenditure and trade openness on private loans, and the magnitudes of these effects are economically substantial. A one percent change in government expenditure, for example, is associated with an increase of 0.2 percent in private loans within six years of the shock, while a one percent change in trade is associated with a 0.17 percent change in private loans within eight years.

\section{[INSERT FIG. 3 AND FIG. 4 HERE]}

\footnotetext{
${ }^{14}$ We form the VECM by inserting the stationary linear combination of the data (i.e., the ECT) at a single lag into an otherwise standard VAR in first differences with four lags, and normalise the co-integrating vector on the Bank of England's private loans.
} 
In light of our historical findings for England, we now ask whether our hypothesis, namely that governments and trade can contribute to a "big push" by promoting development of the financial sector, has some support in more modern data. To this end, we obtained cross section and panel data on financial and macroeconomic indicators for 84 countries over the period from 1960 to 2004 from the 2009 edition of the World Bank's World Development Indicators. ${ }^{15}$ The selection of countries is based on data availability from this source.

As before, we measure trade openness as the ratio of imports plus exports. Government is measured as final expenditures, excluding the military. ${ }^{16}$ For comparability with other studies, we use three familiar measures of financial development, namely liquid liabilities (M3), liquid liabilities less narrow money (M3 less M1), and credit allocated to the private sector. To facilitate cross-country analysis, we express all variables as percentages of gross domestic

15 The 84 countries are Algeria, Argentina, Australia, Austria, Bangladesh, Barbados, Belgium, Bolivia, Brasil, Cameroon, Canada, Central African Republic, Chile, Colombia, Costa Rica, Cote d'Ivoire, Denmark, Dominican Republic, Ecuador, Egypt, El Salvador, Fiji, Finland, France, Gambia, Ghana, Greece, Guatemala, Guyana, Haiti, Honduras, Iceland, India, Indonesia, Iran, Ireland, Israel, Italy, Jamaica, Japan, Jordan, Kenya, Republic of Korea, Lesotho, Luxembourg, Malawi, Malaysia, Malta, Mauritius, Mexico, Morocco, Nepal, Netherlands, New Zealand, Nicaragua, Niger, Nigeria, Norway, Pakistan, Panama, Papua New Guinea, Paraguay, Peru, Philippines, Portugal, Rwanda, Senegal, Sierra Leone, South Africa, Spain, Sri Lanka, Sudan, Sweden, Switzerland, Syrian Arab Republic, Thailand, Trinidad and Tobago, Togo, Turkey, United Kingdom, United States, Uruguay, Venezuela, and Zimbabwe.

${ }^{16}$ It is reasonable to exclude military expenditures from our measure of government for the post1960 period given that wars have not been a mechanism through which financial sectors have emerged and their inclusion would distort identification of the agglomeration effects that we hypothesise. In this respect the role of wars in financial development today differs considerably from that in the earlier days of British economic emergence. 
product (GDP). Liquid liabilities as a percentage of GDP have become a standard measure of financial depth and an indicator of the overall size of financial intermediary activity in crosscountry studies. M3 less M1 removes the pure transactions asset to focus more on the intensity of intermediation, and the credit measure isolates intermediation to the private sector from credit allocated to government or state enterprises. We average the data over five-year periods to build a maximum of nine time series observations for each country starting with 1960-64 and ending with 2000-2004.

Consistent with our hypothesis, the starting point is a set of cross-country regressions of the form

$$
\mathrm{FD}_{\mathrm{it}}=\alpha_{0}+\alpha \mathrm{GOV}_{\mathrm{it}}+\beta \mathrm{TRD}_{\mathrm{it}}+\partial \mathrm{X}_{\mathrm{it}}+\mathrm{u}_{\mathrm{it}}
$$

where $\mathrm{FD}_{\mathrm{it}}$ is a measure of financial development, $\mathrm{GOV}_{\mathrm{it}}$ is government expenditure, $\mathrm{TRD}_{\mathrm{it}}$ is trade openness, and $\mathrm{X}_{\mathrm{it}}$ is a set of baseline explanatory variables that have been shown empirically to be robust determinants of growth. We then estimate a second set of regressions that reverse the positions of trade openness and financial development

$$
\mathrm{TRD}_{\mathrm{it}}=\alpha_{0}+\alpha \mathrm{GOV}_{\mathrm{it}}+\beta \mathrm{FD}_{\mathrm{it}}+\partial \mathrm{X}_{\mathrm{it}}+\mathrm{v}_{\mathrm{it}} .
$$

The conditioning set (i.e., the $\mathrm{X}_{\mathrm{it}}$ ) for the financial development regressions includes per capita income and CPI inflation, in accordance with the empirical literature on the determinants of financial development (Rousseau and Wachtel, 2002; Baltagi et al., 2009). The trade openness regressions additionally condition on the initial value of aggregate GDP in each fiveyear period to capture the effects of country size on trade. We anticipate that country size matters in a negative way when it comes to trade openness in that, all other things equal, larger 
countries need to trade less than smaller countries, as consumers and firms are able to source a greater range of products domestically at lower cost. Estimation is by instrumental variables to ameliorate potential problems of simultaneity. Specifically, we attempt to extract the predetermined component of the financial variable by using its initial value (in each five-year period) along with the initial values of government expenditure and trade as percentages of GDP as instruments in each regression equation.

Table 2 presents estimates of the regressions specified in (1) and (2) using the full set of five-year observations in our 84-country sample. All estimates include time period fixed effects. The coefficient on trade openness is highly statistically significant in all three financial development regressions (see left side of table) and so is the coefficient on initial GDP per capita, but neither government expenditure or CPI inflation is statistically significant.

\section{[INSERT TABLE 2 HERE]}

Table 3 and Table 4 examine the extent to which the results reported in Table 2 vary with per capita income by running quartile regressions. In the interest of space these tables report results using only liquid liabilities as a percentage of GDP as the financial variable, but the findings are broadly similar with our other two measures of financial development. The estimates reported in both tables suggest that both relationships vary considerably according to country income levels, hence relying on the aggregate results in Table 2 can be misleading.

\section{[INSERT TABLE 3 HERE]}

The results in Table 3 reveal that government expenditure has a positive and highly significant effect on financial development in the second and third income quartiles. Its effect in 
the first quartile is positive but not significant while it is negative and highly significant in the fourth quartile. These results suggest that at very low income levels, government spending does not seem to promote more intense financial intermediation, possibly reflecting a country's reliance on foreign aid and soft international loans in the early stages of development. At intermediate levels of income, governments' financing requirements will need to be at least partially satisfied from domestic sources, which may explain why government spending impacts positively on the development of the domestic financial system. The reversal of this effect at high levels of income suggest that high public sector borrowing requirements in developed economies impact negatively on the size of the banking system. This may be because in developed economies, the growth of the public sector may crowd out rather than crowd in the private sector. If the private sector relies more on the banking system than the public sector, crowding out of the former by the latter is likely to result in a smaller banking system.

Trade openness also has a positive and highly significant effect on financial depth in the second and third quartiles, a negative one in the fourth and an insignificant one in the first. The positive effect of trade openness on financial development is consistent with existing empirical literature (e.g., Baltagi et al., 2009) as well as with the great reversals hypothesis of Rajan and Zingales (2003). The positive and insignificant effect of trade openness on financial development in poor countries is perhaps not very surprising as it may to some extent be a reflection of more noisy data and a smaller number of observations. What is perhaps harder to explain is the negative and significant effect found for the fourth quartile. A plausible explanation for this finding needs perhaps to recognise the role that money and capital markets can play in promoting trade in developed economies. If, for example, firms can obtain cheaper trade finance from money and capital markets than from banks, greater trade openness could 
well be associated with lower levels of banking system development.

\section{[INSERT TABLE 4 HERE]}

The estimates reported in Table 4 show that government expenditure impacts positively on trade openness at low and high income levels, but has no significant influence at intermediate levels of income. At low income levels, this may reflect the developmental nature of government expenditures - infrastructure projects for example are likely to have high import content. As countries develop, their capacity to undertake such projects domestically is likely to improve, which can explain the insignificant coefficient at the intermediate income levels. On the other hand, the positive and larger in magnitude coefficient of government expenditure at high income levels is somewhat puzzling. It suggests that high government expenditures at these levels are trade promoting, but it is not obvious why.

The effects of financial development on trade openness are interesting and much less surprising. It appears that they tend to decline with income, being at their highest at low income levels, suggesting that financial development may have some if not all of its growth promoting effects early on by supporting trade. For the fourth income quartile the effects of financial development are small and significant only at the ten percent level. In the intermediate region the effects taper off but are still sizeable and significant, suggesting that financial development continues to be important in promoting economic openness in such countries. Interestingly, the effects of per capita income on trade are significant only in the first and second quartiles while the negative-size effect is highly significant in all quartiles.

The results in Table 3 and Table 4 confirm that the aggregate results mask important variation that exists among different groups of countries. Different policy recommendations 
may therefore be appropriate for different stages of development. At low income levels, economic development is the only variable that appears to drive financial development, since both trade openness and government spending have positive and insignificant coefficients at conventional levels. At intermediate income levels, both government expenditure and trade openness are significant drivers of banking system development. At high levels of income both these effects are reversed, reflecting perhaps the increased role played by money and capital markets and crowding out of the private sector by the government.

At the very initial stages of development, government spending seems to support trade. It is only later, when the commercial sector is more developed, that government expenditure would be directed toward trade-promoting infrastructure such as ports, railroads, and roads, which ultimately create income that feeds back into the financial sector. As economic development progresses, government expenditure begins to facilitate the emergence of domestic finance, because governments begin to borrow from domestic banks, which are able to mobilise more savings.

\section{CONCLUDING REMARKS}

We make a first attempt to examine empirically the interactions between government expenditure, trade openness and financial development utilising data from 18th century England and a panel of 84 countries from 1960-2004. For England, we find that the government and international trade did have positive effects on financial development when measured as the value of private loans issued at the Bank of England. For the wider panel of countries and more recent data, we find that government expenditure seems to have positive effects on financial development for countries that are in the mid-ranges of economic development as measured by 
per capita income, but has little effect for poor countries and a strongly negative effect for the wealthiest ones.

The historical and more modern analyses are both consistent with a mutually supportive government-trade-finance nexus that reaches its peak of effectiveness once an economy begins to modernise. England, for example, had shown signs of modernising prior to the Glorious Revolution of 1688 , but military conflicts and the rise of a stronger Parliamentary state allowed the Bank of England to form and evolve along with a host of other financial institutions, setting the nexus into motion. Indeed, with a per capita income of more than $\$ 1,000$ (1990 US) by 1770 , England would have been firmly in the second quartile of our broad cross-section of economies measured in 1990.

When considering whether aspects of the British historical experience might be found in other early-industrialising nations, the United States immediately comes to mind. Though financially under-developed at the time of its War of Independence from 1776 to 1783 , resources were needed to fight the war and the provisional government resorted to printing fiat money and later to issuing debt to Dutch and French investors. These issues allowed the fledgling nation to support its war effort, but rapid depreciation of its currency and the disorganised state of public finances led its debts to trade at pennies on the dollar by the mid-1780s. But it was from these depths that the nation's first Secretary of the Treasury, Alexander Hamilton, engineered a "Federalist financial revolution" that involved setting up a central bank, refinancing the war debts, and watching the new instruments rise to par within months as confidence in the U.S. government and financial system grew among foreign investors (Rousseau and Sylla, 2005). This early financial success set the stage for funding subsequent military needs as well as public infrastructure projects such as canals, roads and bridges that facilitated private commerce. 
Our study takes exception to the usual view that government expenditure in general has a crowding-out effect on private investment, and suggests that the government itself is essential to the development of sound financial arrangements. The effects of such a nexus, with the emergence of a modern sector reflected in the extent of international trade, are most emphatic as economies begin to experience robust growth. This has strong implications for the staging of development policies today. 


\section{REFERENCES}

Andrianova, S., Demetriades, P. and Xu, C. (2011). 'Political Economy Origins of Financial Markets in Europe and Asia', UWorld Development, Vol. 39, No. 4, pp. 686-699.

Baltagi, B. H., Demetriades, P. O. and Law, S. H. (2009). 'Financial Development and Openness: Evidence from Panel Data', Journal of Development Economics, Vol 89, No. 2, pp. 285-296.

Banerjee, A., Dolado, J. J., Galbraith, J. W. and Hendy, D. F. (1993). Co-integration, Error Correction, and the Econometric Analysis of Non-Stationary Data, Oxford, Oxford University Press.

Ben-David, D. (1993). 'Equalising Exchange: Trade Liberalisation and Income Convergence', Quarterly Journal of Economics, Vol. 108, No. 3, pp. 653-679.

Bougheas, S., Demetriades, P. O. and Mamuneas, T. P. (2000). 'Infrastructure, Specialisation and Economic Growth', Canadian Journal of Economics, Vol. 33, No. 2, pp. 506-522.

Bougheas, S., Demetriades, P. O. and Morgenroth, E. L. W. (1999). 'Infrastructure, Transport Costs and Trade', Journal of International Economics, Vol. 47, No. 1, pp. 169-189.

Brewer, J. (1989). The Sinews of Power: War, Money and the English State, 1688-1783, Cambridge, MA: Harvard University Press.

Cameron, R. (1967). 'England, 1750-1844', in (R. Cameron, O. Crisp, H. T. Patrick, and R. Tilly, eds.) Banking in the Early Stages of Industrialisation: A Study in Comparative Economic History, pp. 15-59. New York: Oxford University Press.

Clapham, J. H. (1941). 'The Private Business of the Bank of England, 1744-1800', Economic History Review, Vol. 11, No. 1, pp. 77-89.

Clapham, J. H. (1945). The Bank of England: A History, New York: Macmillan.

Crafts, N. F. R. (1987). 'British Economic Growth, 1700-1850: Some Difficulties of Interpretation', Explorations in Economic History, Vol. 24, No. 3, pp. 245-268.

de Vries, J. (1976). The Economy of Europe in an Age of Crisis, 1600-1750, Cambridge: Cambridge University Press.

de Vries, J. and van der Woude, A. (1997). The First Modern Economy: Success, Failure, and Perseverance of the Dutch Economy, 1500-1815, Cambridge: Cambridge University Press.

Demetriades, P. O. and Hussein, K. (1996). 'Does Financial Development Cause Growth?: Time Series Evidence from 16 Countries', Journal of Development Economics, Vol. 51, No. 2, pp. $387-411$ 
Dickson, P. G. M. (1967). The Financial Revolution in England: A Study in the Development of Public Credit, 1688-1756, London: Macmillan.

Dollar, D. (1992). 'Outward-oriented Developing Countries Really Do Grow More Rapidly: Evidence from 95 LDCs', Economic Development and Cultural Change, Vol. 40, No. 3, pp. 523-544.

Edwards, S. (1998). 'Openness, Productivity and Growth: What Do We Really Know?', Economic Journal, Vol. 108, No. 447, pp. 383-398.

Easterly, W. and Rebelo, S. (1993). 'Fiscal Policy and Economic Growth: An Empirical Investigation', Journal of Monetary Economics, Vol. 32, No. 3, pp. 417-458.

Jackson, R. V. (1990). 'Government Expenditure and British Economic Growth in the Eighteenth Century: Some Problems of Measurement', Economic History Review, Vol. 43, No. 2, pp. 217-235.

Johansen, S. (1991). 'Estimation and Hypothesis Testing of Cointegration Vectors in Gaussian Vector Autoregressive Models', Econometrica, Vol. 59, No. 6, pp. 1551-1580.

Levine, R. (2005). 'Finance and Growth: Theory and Evidence', in (P. Aghion and S. N. Durlauf, eds.) Handbook of Economic Growth, Vol. 1A, pp. 865-934. Amsterdam: Elsevier North Holland.

Levine, R. (1997). 'Financial Development and Economic Growth: Views and Agenda', Journal of Economic Literature, Vol. 35, No. 2, pp. 688-726.

Mitchell, B. R. (1988). British Historical Statistics, Cambridge: Cambridge University Press.

Mokyr, J. (1987). 'Has the Industrial Revolution Been Crowded Out? Some Reflections on Crafts and Williamson', Explorations in Economic History, Vol. 24, No. 3, pp. 293-319.

Neal, L. (1990). The Rise of Financial Capitalism: International Capital Markets in the Age of Reason, New York: Cambridge University Press.

North, D. C. and Weingast, B. R. (1989). 'Constitutions and Commitment', Journal of Economic History, Vol. 49, No. 4, pp. 803-832.

Osterwald-Lenum, M. (1992). 'A Note with Fractiles of the Asymptotic Distribution of the Maximum Likelihood Cointegration Rank Test Statistics: Four Cases', Oxford Bulletin of Economics and Statistics, Vol. 54, No. 3, pp. 461-478.

Rajan, R. G. and Zingales, L. (2003) 'The Great Reversals: The Politics of Financial Development in the Twentieth Century', Journal of Financial Economics, Vol. 69, No. 1, pp. $5-50$. 
Rioja, F. and Valev, N. (2004). 'Does One Size Fit All?: A Reexamination of the Finance and Growth Relationship', Journal of Financial Economics, Vol. 74, No. 2, pp. 429-447.

Richards, R. D. (1934). 'The First Fifty Years of the Bank of England', in (J. G. Van Dillen, ed.) History of the Public Banks: Accompanied by Extensive Bibliographies of the Histories of Banking and Credit in Eleven European Countries, pp. 201-72. The Hague: M. Nijhoff.

Rousseau, P. L. (2003). 'Historical Perspectives on Financial Development and Economic Growth', Federal Reserve Bank of St. Louis Review, Vol. 84, No. 4, pp. 81-105.

Rousseau, P. L. and Sylla, R. (2003). 'Financial Systems, Economic Growth, and Globalisation”, in (M. D. Bordo, A. M. Taylor, and J. G. Williamson, eds.) Globalisation in Historical Perspective, pp. 373-413. Chicago: University of Chicago Press for National Bureau of Economic Research.

Rousseau, P. L. and Sylla, R. (2005). 'Emerging Financial Markets and Early US Growth', Explorations in Economic History, Vol. 42, No. 1, pp. 1-26.

Rousseau, P. L., and Wachtel, P. (2002). 'Inflation Thresholds in the Finance-Growth Nexus', Journal of International Money and Finance, Vol. 21, No. 6, pp. 777-93.

Rousseau, P. L., and Wachtel, P. (2011). 'What is Happening to the Impact of Financial Deepening on Economic Growth', Economic Inquiry, Vol. 49, No. 1, pp. 276-288.

Sachs, J. and Warner, A. (1995). 'Economic Reform and the Process of Global Integration', Brookings Papers on Economic Activity, No. 1, pp. 1-118.

Sims, C. A., Stock, J. H., and Watson, M. W. (1990). 'Inference in Time Series Models with Some Unit Roots', Econometrica, Vol. 58, No. 1, pp. 113-144.

Svaleryd, H. and Vlachos, J. (2002). 'Markets for Risk and Openness to Trade: How Are They Related', Journal of International Economics, Vol. 57, No. 2, pp. 369-395.

Sylla, R. (1999). 'Shaping the U.S. Financial System, 1690-1913', in (R. Sylla, R. Tilly and G. Tortella, eds.) The State, the Financial System, and Economic Modernisation, pp. 249-70. Cambridge: Cambridge University Press.

Toda, H. and Yamamoto, T. (1995). 'Statistical Inference in Vector Autoregressions with Possibly Near Integrated Processes', Journal of Econometrics, Vol. 66, No. 1-2, pp. 225-250.

Williamson, J. G. (1984). 'Why Was British Growth So Slow During the Industrial Revolution', Explorations in Economic History, Vol. 44, No. 3, pp. 687-712. 
TABLE 1

Government, Trade AND PRIVATE LoAns MAdE By THE BANK of ENGLAND, 1728-1799

Levels VAR results and block exogeneity tests

\begin{tabular}{|c|c|c|c|c|}
\hline \multirow{2}{*}{$\begin{array}{c}\text { Dependent variable } \\
\text { Bank of England } \\
\text { private loans }\end{array}$} & $\begin{array}{c}\text { Regressors } \\
\text { Trade }\end{array}$ & $\begin{array}{c}\text { Government } \\
\text { expenditure }\end{array}$ & $\begin{array}{c}R^{2} \\
(D W)\end{array}$ \\
\hline Bank of England & 0.8377 & 1.4701 & 0.6522 & 0.921 \\
private loans & $(0.000)$ & $(0.019)$ & $(0.000)$ & $(1.97)$ \\
\hline Trade & {$[0.000]$} & {$[0.039]$} & {$[0.001]$} & 0.558 \\
& 0.0040 & 0.7476 & 0.0226 & $(2.01)$ \\
\hline Government & $(0.817)$ & $(0.000)$ & {$[0.905)$} & 0.867 \\
expenditure & {$[0.928]$} & {$[0.000]$} & 0.6977 & $(2.11)$ \\
\hline
\end{tabular}

Vector error correction analysis

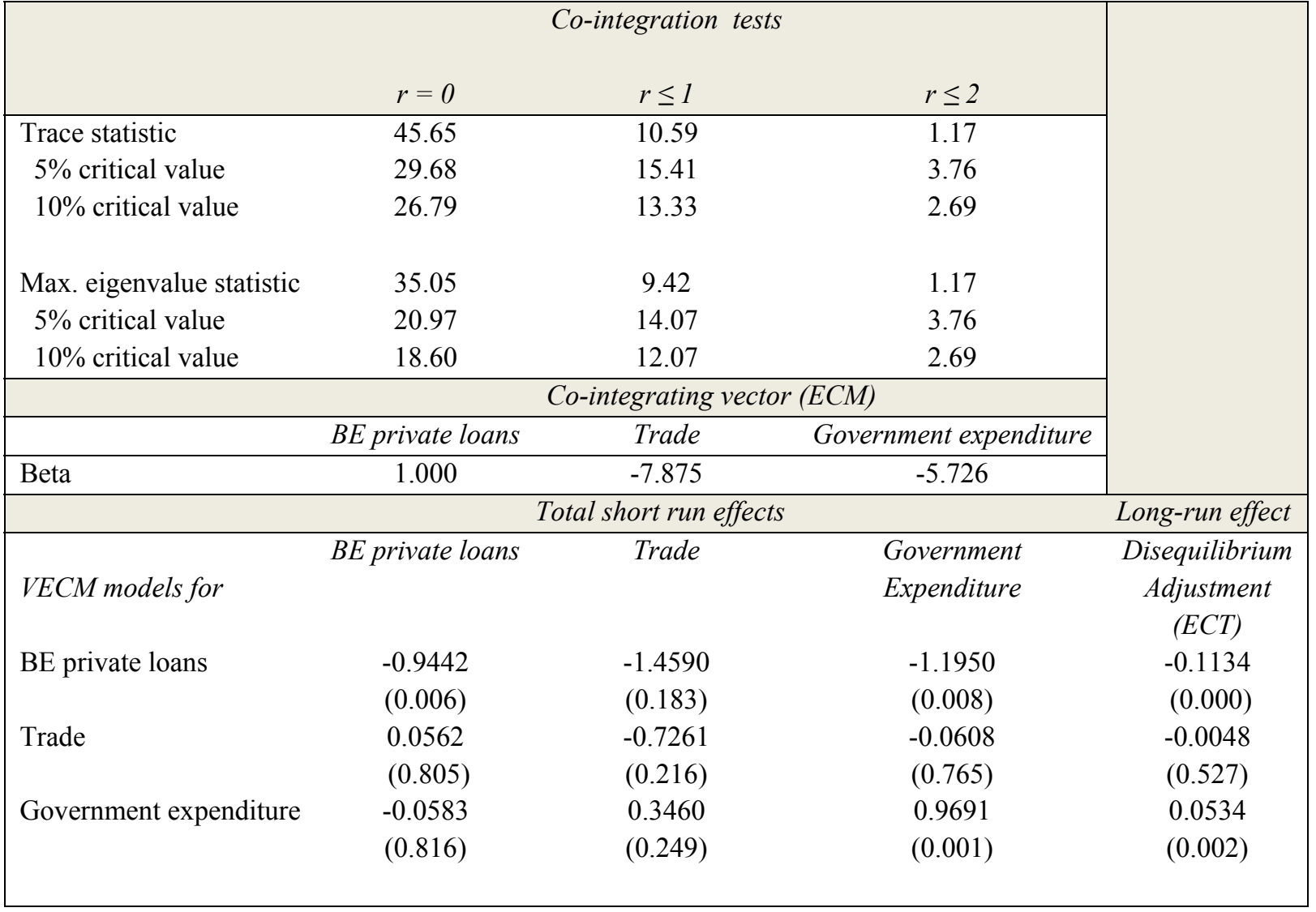

Notes: The VAR includes five lags of all variables in log real per capita terms. The table reports the sum of the lag coefficients for each variable block in the VAR and VECM models, with p-values for block Granger causality in parentheses. Figures in square brackets are p-values for the modified Wald tests developed by Toda and Yamamoto (1995). Critical values for the Johansen (1991) co-integration tests are from Table 1 in Osterwald-Lenum (1992). 
TABLE 2

Financial DeVelopment AND TRAde Openness in a PANel of COUNTRIES, 1960-2004 INSTRUMENTAL VARIABLE REGRESSIONS WITH 5-YEAR PANEL DATA

\begin{tabular}{|c|c|c|c|c|c|c|}
\hline \multirow[b]{2}{*}{ Regressors } & \multicolumn{6}{|c|}{ Dependent variable } \\
\hline & $\begin{array}{c}M 3 \\
\% \text { of } G D P\end{array}$ & $\begin{array}{c}M 3-M 1 \\
\% \text { of } G D P \\
\end{array}$ & $\begin{array}{c}\text { Private credit } \\
\% \text { of } G D P\end{array}$ & $\begin{array}{c}\text { Trade openness } \\
\% \text { of } G D P\end{array}$ & $\begin{array}{c}\text { Trade openness } \\
\% \text { of } G D P\end{array}$ & $\begin{array}{c}\text { Trade openness } \\
\text { \% of } G D P\end{array}$ \\
\hline $\begin{array}{l}\text { Government expenditure } \\
(\% \text { of GDP) }\end{array}$ & $\begin{array}{c}0.168 \\
(0.228)\end{array}$ & $\begin{array}{l}-0.128 \\
(0.144)\end{array}$ & $\begin{array}{c}0.154 \\
(0.222)\end{array}$ & $\begin{array}{l}1.193^{* * *} \\
(0.204)\end{array}$ & $\begin{array}{l}1.326^{* * *} \\
(0.205)\end{array}$ & $\begin{array}{l}1.180^{* * *} \\
(0.226)\end{array}$ \\
\hline $\begin{array}{l}\text { Trade openness } \\
(\% \text { of GDP) }\end{array}$ & $\begin{array}{l}0.237^{* * *} \\
(0.034)\end{array}$ & $\begin{array}{l}0.186^{* * *} \\
(0.021)\end{array}$ & $\begin{array}{l}0.065^{* * *} \\
(0.030)\end{array}$ & --- & --- & --- \\
\hline $\begin{array}{l}\text { Liquid liabilities (M3) } \\
\text { (\% of GDP) }\end{array}$ & --- & --- & --- & $\begin{array}{l}0.386^{* * *} \\
(0.037)\end{array}$ & --- & --- \\
\hline $\begin{array}{l}\text { M3-M1 } \\
(\% \text { of GDP) }\end{array}$ & --- & --- & --- & --- & $\begin{array}{l}0.619^{* * *} \\
(0.058)\end{array}$ & --- \\
\hline $\begin{array}{l}\text { Private credit } \\
(\% \text { of GDP) }\end{array}$ & --- & --- & --- & --- & --- & $\begin{array}{l}0.289^{* * *} \\
(0.044)\end{array}$ \\
\hline $\begin{array}{l}\text { Initial real GDP per capita } \\
\text { (in } 2000 \text { US\$) }\end{array}$ & $\begin{array}{l}10.476^{* * *} \\
(0.716)\end{array}$ & $\begin{array}{l}7.627^{* * *} \\
(0.452)\end{array}$ & $\begin{array}{l}14.797^{* * *} \\
(0.695)\end{array}$ & $\begin{array}{l}7.701^{* * *} \\
(0.992)\end{array}$ & $\begin{array}{l}6.748^{* * *} \\
(1.051)\end{array}$ & $\begin{array}{l}10.965^{* * *} \\
(1.130)\end{array}$ \\
\hline $\begin{array}{l}\text { Initial aggregate GDP } \\
\text { (in } 2000 \text { US\$) }\end{array}$ & --- & --- & --- & $\begin{array}{l}-12.352^{* * *} \\
(0.633)\end{array}$ & $\begin{array}{l}-11.739^{* * *} \\
(0.640)\end{array}$ & $\begin{array}{l}-14.440^{* * *} \\
(0.706)\end{array}$ \\
\hline CPI Inflation & $\begin{array}{l}-0.005 \\
(0.005)\end{array}$ & $\begin{array}{l}-0.004 \\
(0.003)\end{array}$ & $\begin{array}{l}-0.007 \\
(0.005)\end{array}$ & $\begin{array}{c}-0.012^{* *} \\
(0.005)\end{array}$ & $\begin{array}{c}-0.011^{* *} \\
(0.005)\end{array}$ & $\begin{array}{l}-0.013^{* * *} \\
(0.005)\end{array}$ \\
\hline $\mathrm{R}^{2}$ & 0.401 & 0.469 & 0.529 & 0.55 & 0.55 & 0.51 \\
\hline No. of observations & 630 & 626 & 653 & 630 & 626 & 653 \\
\hline
\end{tabular}

Notes: Instruments include initial values of all regressors other than CPI inflation. Figures in parentheses are standard errors. All regressions include a full set of dummy variables for five-year time periods. The symbols ${ }^{* * * *}$ and ${ }^{*}$ denote statistical significance at the $1 \%, 5 \%$ and $10 \%$ levels, respectively. 
TABLE 3

Financial DeVelopment in A PANEl of Countries, 1960-2004

INSTRUMENTAL VARIABLE QUARTILE REGRESSIONS WITH 5-YEAR PANEL DATA

\begin{tabular}{|c|c|c|c|c|}
\hline \multirow[b]{2}{*}{ Regressors } & \multicolumn{4}{|c|}{ Dependent variable: Liquid Liabilities (M3 as \% of GDP) } \\
\hline & $1^{\text {st }}$ Quartile & $2^{\text {nd }}$ Quartile & $3^{\text {rd }}$ Quartile & $4^{\text {th }}$ Quartile \\
\hline $\begin{array}{l}\text { Government expenditure } \\
(\% \text { of GDP) }\end{array}$ & $\begin{array}{l}-0.076 \\
(0.249)\end{array}$ & $\begin{array}{l}2.031^{* * *} \\
(0.307)\end{array}$ & $\begin{array}{l}2.423^{* * *} \\
(0.703)\end{array}$ & $\begin{array}{l}-2.246^{* * *} \\
(0.551)\end{array}$ \\
\hline $\begin{array}{l}\text { Trade Openness } \\
(\% \text { of GDP) }\end{array}$ & $\begin{array}{c}0.057 \\
(0.036)\end{array}$ & $\begin{array}{l}0.283^{* * *} \\
(0.076)\end{array}$ & $\begin{array}{l}0.459^{* * *} \\
(0.050)\end{array}$ & $\begin{array}{l}-0.196^{* *} \\
(0.091)\end{array}$ \\
\hline $\begin{array}{l}\text { Initial real GDP per capita } \\
\text { (in } 2000 \text { US\$) }\end{array}$ & $\begin{array}{l}14.22^{* * *} \\
(2.612)\end{array}$ & $\begin{array}{l}5.953^{* *} \\
(2.800)\end{array}$ & $\begin{array}{l}12.279^{* * *} \\
(3.498)\end{array}$ & $\begin{array}{l}23.243^{* * *} \\
(7.134)\end{array}$ \\
\hline CPI Inflation & $\begin{array}{l}-0.075 \\
(0.073)\end{array}$ & $\begin{array}{l}-0.011^{* * *} \\
(0.004)\end{array}$ & $\begin{array}{l}0.316^{* *} \\
(0.162)\end{array}$ & $\begin{array}{l}-0.039^{* *} \\
(0.016)\end{array}$ \\
\hline $\mathrm{R}^{2}$ & 0.40 & 0.55 & 0.56 & 0.33 \\
\hline No. of observations & 136 & 172 & 163 & 159 \\
\hline
\end{tabular}

Notes:

1. Quartiles are defined in accordance to US\$ income levels in 1990. The first quartile includes countries with GDP per capita of up to $\$ 660$, while the upper cut-offs for the second, third and fourth quartiles are $\$ 1,659, \$ 8,947$ and $\$ 33,297$ respectively.

2. Instruments include initial values of government expenditure and trade openness.

3. Figures in parentheses are standard errors.

4. All regressions include a full set of time dummies.

5. The symbols ${ }^{* * * *}$ and ${ }^{*}$ denote statistical significance at the $1 \%, 5 \%$ and $10 \%$ levels, respectively. 
TABLE 4

Trade Openness in a PANel of Countries, 1960-2004

INSTRUMENTAL VARIABLE QUARTILE REGRESSIONS WITH 5-YEAR PANEL DATA

\section{Dependent variable: Trade Openness}

\begin{tabular}{lcccc} 
Regressors & $1^{\text {st }}$ Quartile & $2^{\text {nd }}$ Quartile & $3^{\text {rd }}$ Quartile & $4^{\text {th }}$ Quartile \\
\hline $\begin{array}{l}\text { Government expenditure } \\
\text { (\% of GDP) }\end{array}$ & $1.343^{* * *}$ & 0.273 & -0.596 & $2.026^{* * *}$ \\
& $(0.436)$ & $(0.361)$ & $(0.799)$ & $(0.429)$ \\
$\begin{array}{l}\text { Liquid liabilities (M3) } \\
\text { (\% of GDP) }\end{array}$ & $0.819^{* * *}$ & $0.505^{* * *}$ & $0.613^{* * *}$ & $0.121^{*}$ \\
& $(0.213)$ & $(0.083)$ & $(0.072)$ & $(0.072)$ \\
Initial real GDP per capita & $26.576^{* * *}$ & $5.521^{* *}$ & -0.979 & 4.402 \\
(in 2000 US\$) & $(5.352)$ & $(2.750)$ & $(3.904)$ & $(5.554)$ \\
$\begin{array}{l}\text { Initial aggregate GDP } \\
\text { (in 2000 US\$) }\end{array}$ & $-12.273^{* * *}$ & $-6.814^{* * *}$ & $-13.771^{* * *}$ & $-10.447^{* * *}$ \\
CPI Inflation & $(1.315)$ & $(1.252)$ & $(1.450)$ & $(1.274)$ \\
& 0.013 & -0.005 & -0.015 & $-0.227^{*}$ \\
$\mathrm{R}^{2}$ & $(0.132)$ & $(0.004)$ & $(0.013)$ & $(0.127)$ \\
No. of observations $^{\text {N }}$ & 0.65 & 0.52 & 0.73 & 0.47 \\
\hline
\end{tabular}

Notes:

1. Quartiles are defined in accordance to US\$ income levels in 1990. The first quartile includes countries with GDP per capita of up to $\$ 660$, while the upper cut-offs for the second, third and fourth quartiles are $\$ 1,659, \$ 8,947$ and $\$ 33,297$ respectively.

2. Instruments include initial values of government expenditure and liquid liabilities.

3. Figures in parentheses are standard errors.

4. All regressions include a full set of five-year time dummies.

5. The symbols ${ }^{* * * * *}$ and ${ }^{*}$ denote statistical significance at the $1 \%, 5 \%$ and $10 \%$ levels, respectively. 


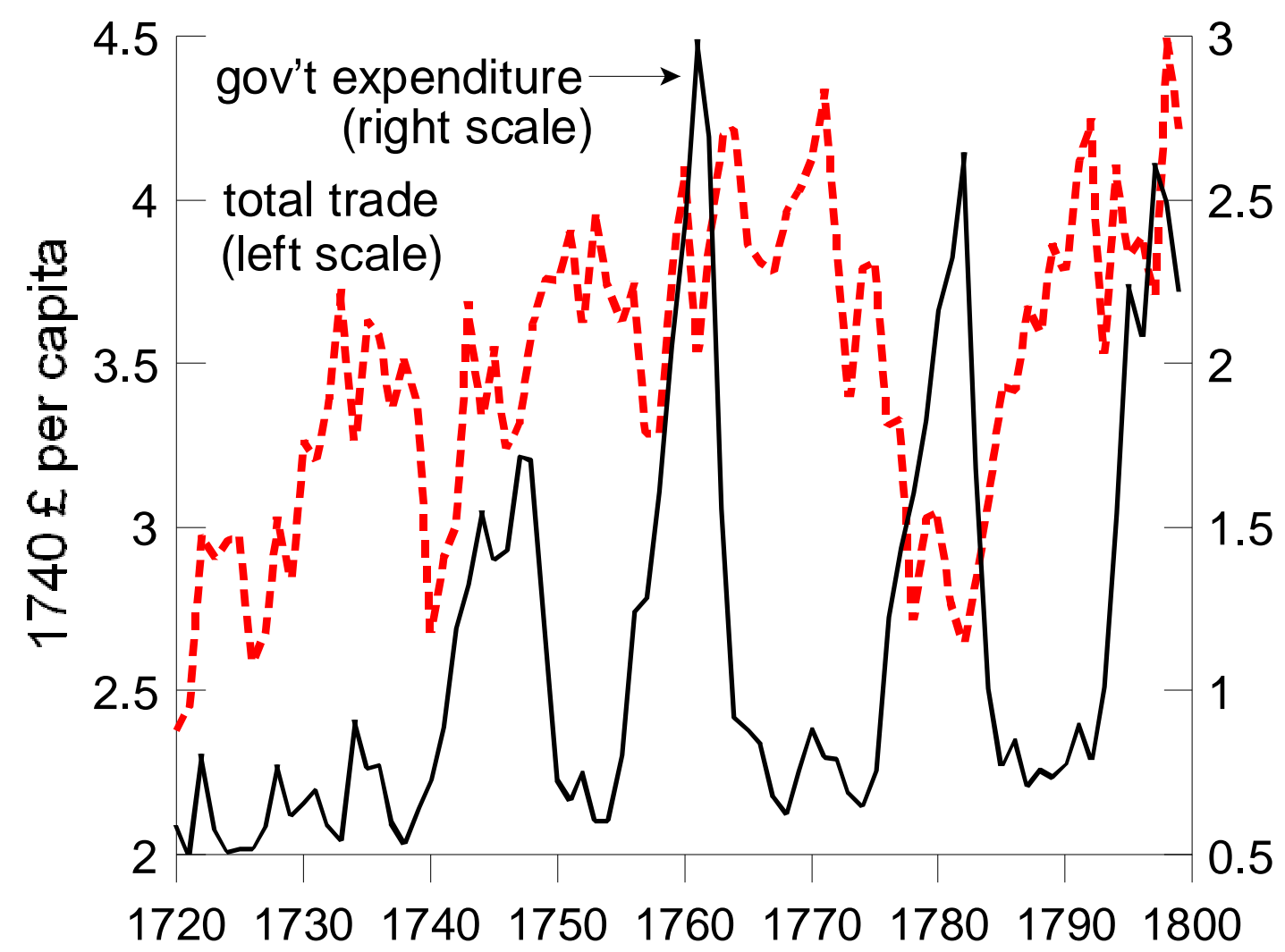

FIG. 1 Real Per Capita British Government Expenditures (Including Military) and Total Trade (Imports, Exports, and Re-exports), 1720-1799 


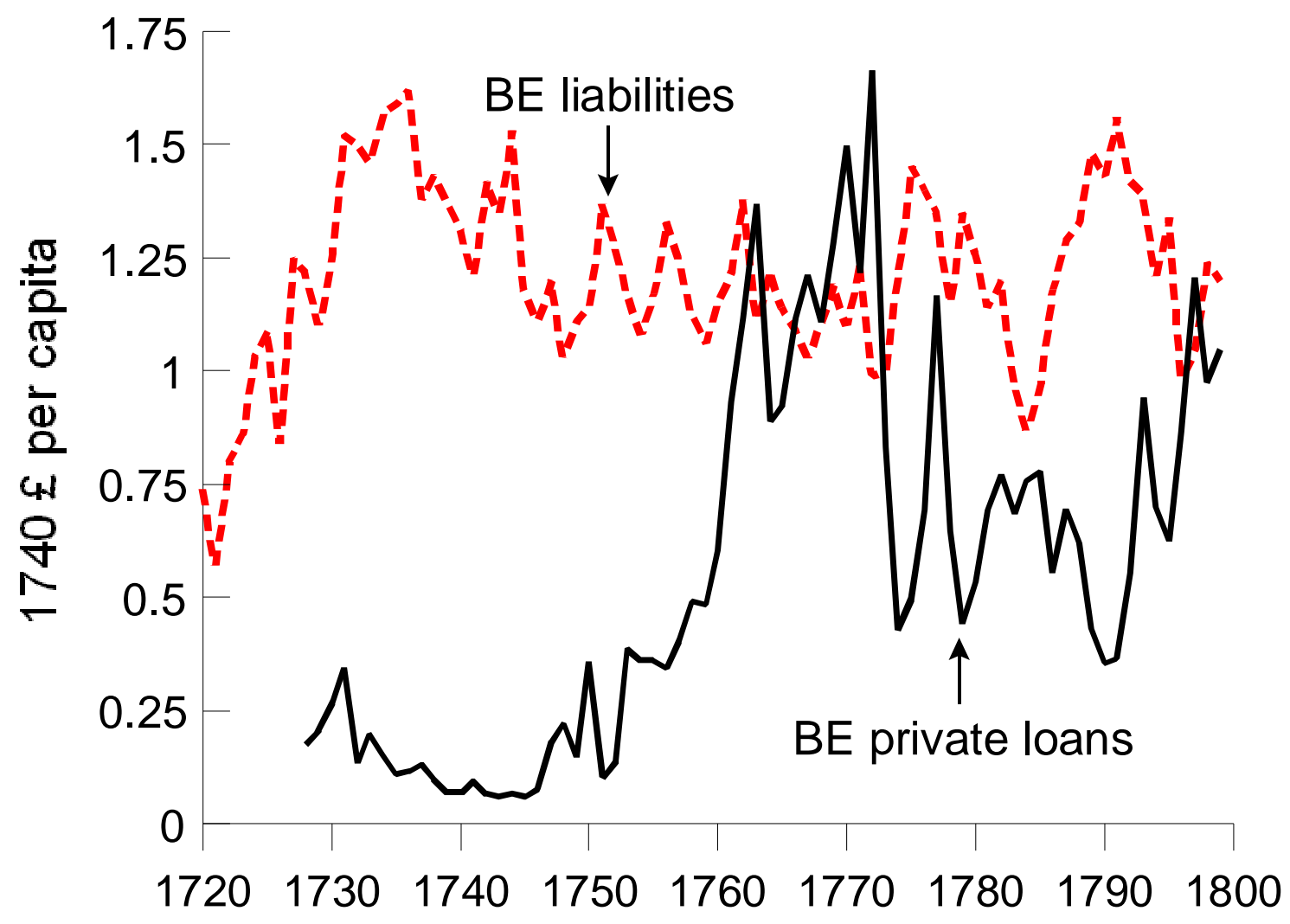

FIG. 2 Real Per Capita Liabilities and Private Loans of the Bank of England, 1720-1799 


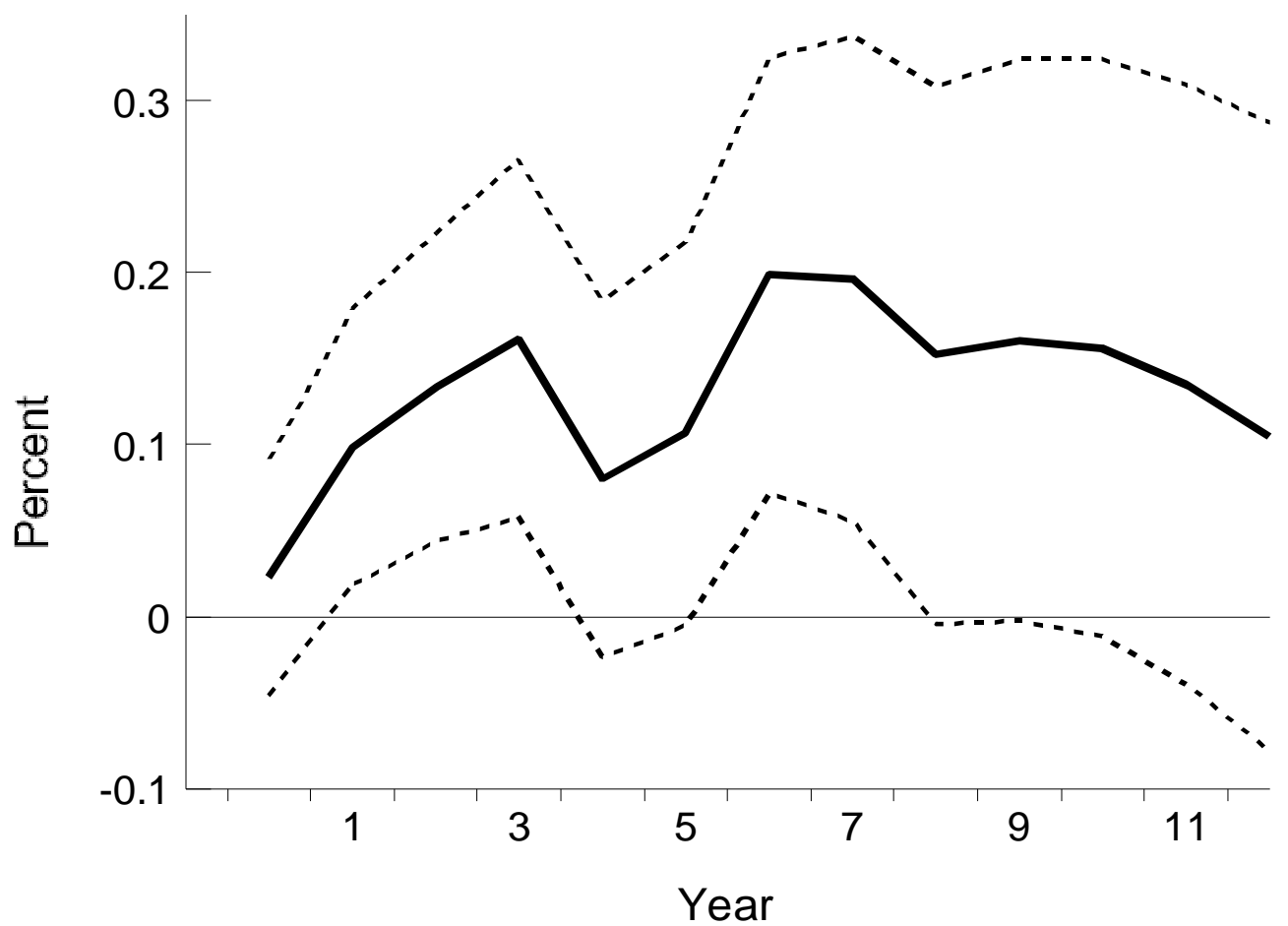

FIG. 3 Effect of Government Expenditure on Private Loans by the Bank of England, 1728-99

Notes: The impulse responses correspond to the levels VAR system reported in Table 1. The plot traces the percent change in private loans made by the Bank of England over a 12-year horizon from a $1 \%$ change in the orthogonalised innovation to government expenditure. The variable ordering places expenditure first, trade second and private loans at the Bank of England last. Using Monte Carlo integration, the thick solid line plots the mean impulse response that results from 10,000 random draws from the posterior distribution of the estimated VAR coefficients. The dashed lines are two standard error bands. 


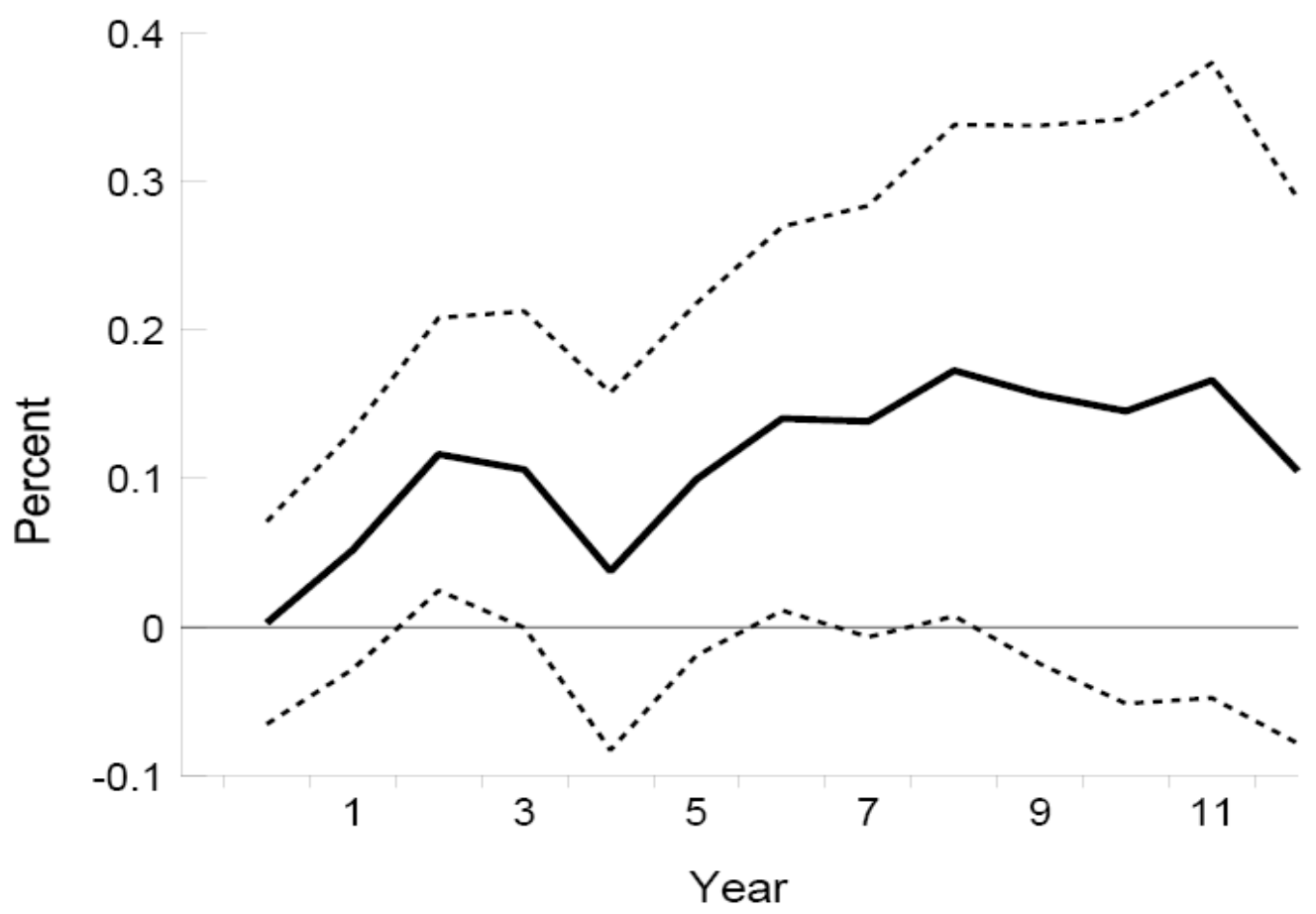

FIG. 4 Effect of International Trade on Private Loans by the Bank of England, 1728-99 See note to Fig. 3. 